\title{
Are "pink puffers" more breathless than "blue bloaters"?
}

\author{
M A JOHNSON, A A WOODCOCK, M REHAHN, D M GEDDES
}

\begin{abstract}
Breathlessness, disability, and exercise tolerance were assessed in 26 patients with severe chronic airflow limitation (forced expiratory volume in one second $\left(F V_{1}\right) \leqslant 1$ litre) divided into two groups-15 patients who were normocapnic (pressure of arterial carbon dioxide $\left(\mathrm{PacO}_{2}\right)<5.5 \mathrm{kPa}(<41.4 \mathrm{~mm} \mathrm{Hg})$ ), and 11 patients who were hypercapnic $\left(\mathrm{PaCO}_{2}>6 \mathrm{kPa}(>45.1\right.$ $\mathrm{mm} \mathrm{Hg})$ ). The two groups were well matched for spirometric values (FEV 0.591 and 0.621 , respectively). All of the hypercapnic patients could improve blood gas tensions towards normal by hyperventilation. There were no significant differences in visual analogue scores of breathlessness during treadmill exercise, disability (oxygen-cost diagram, dyspnoea grade), or exercise tolerance (six-minute walk, maximal consumption of oxygen during bicycle ergometry, distance walked to exhaustion in progressive treadmill test).

The findings show that the "fight" to maintain normal blood gas tensions in the face of severe airflow limitation does not have an appreciable cost in terms of disability.
\end{abstract}

\section{Introduction}

Patients with chronic airflow limitation present clinically as a wide spectrum and those extremes have become known as "pink and puffing" and "blue and bloated." Pink and puffing patients (fighters) are frequently stated to maintain relatively normal blood gas tensions at the expense of breathlessness and are consequently severely disabled, whereas blue and bloated patients (non-fighters) choose to be free of breathlessness and are less disabled, but at the expense of abnormal blood gas tensions and consequent right heart failure. ${ }^{2-8}$ Several studies have investi-

\section{Brompton Hospital, London SW3 6HP}

M A JOHNSON, MB, MRCP, research registrar

A A WOODCOCK, MD, MRCP, research registrar (now senior registrar, St James's Hospital, London SW $128 \mathrm{HW}$ )

M REHAHN, FIS, statistician

D M GEDDES, MD, FRCP, consultant physician gated these polar groups and suggested a difference in exercise tolerance. Such groups, however, have not been well matched for lung function, and breathlessness and disability have not been assessed in detail. 910

We set out to compare detailed measurements of breathlessness, exercise tolerance, and exercise physiology in two polar groups of patients (closely matched for spirometric values) with severe chronic airflow limitation to see whether the fight to maintain normal blood gas tensions has a noticeable cost in terms of increased disability.

\section{Subjects and methods}

Twenty-six patients with chronic airflow limitation (forced expiratory volume in one second $\left(\mathrm{FEV}_{1}\right) \leqslant 1$ litre) were selected from outpatients to fall into two groups-normocapnic (pressure of arterial carbon dioxide $\left(\mathrm{PaCO}_{2}\right)<5.5 \mathrm{kPa}(<41.4 \mathrm{~mm} \mathrm{Hg})$ ) and hypercapnic $\left(\mathrm{PaCO}_{2}>6 \mathrm{kPa}(>45.1 \mathrm{~mm} \mathrm{Hg})\right)$. Patients with a resting $\mathrm{PaCO}_{2}$ between 5.5 and $6 \mathrm{kPa}$ were not selected. Patients with other major medical diagnoses or locomotor disability were excluded. All the patients in the hypercapnic group had had at least one episode of right heart failure, as had three patients in the normocapnic group. Eight of the 11 hypercapnic patients and three of the 15 normocapnic patients were receiving maintenance diuretics, and no patient had evidence of right heart failure at the time of the study. Three patients in each group were smoking at the time of the study, and these patients were requested to stop smoking for 24 hours before exercise testing. Four patients in the normocapnic group and three in the hypercapnic group were maintained with oral steroids $(<10 \mathrm{mg} /$ day). No patient received oral sympathomimetics, and inhaled sympathomimetics were withdrawn at least eight hours before study.

The following measurements were made.

Lung function - $\mathrm{FEV}_{1}$ and forced vital capacity (FVC) were recorded as the best of three measurements on a Vitalograph spirometer, and carbon monoxide transfer factor $\left(\mathrm{T}_{\mathrm{L}} \mathrm{CO}\right)$ measured by the singlebreath method. ${ }^{11}$

Blood gas tensions-Arterialised ear-lobe samples were taken at rest and exhaustion after exercise on the bicycle ergometer. ${ }^{12}$ Patients with a resting $\mathrm{PaCO}_{2}>6 \mathrm{kPa}$ had a further sample taken after one minute of maximal hyperventilation.

Breathlessness and exercise tolerance were assessed from (a) dyspnoea grade $^{13}$ - patients were asked to mark the category which most closely approximated their disability; $(b)$ an oxygen-cost diagram ${ }^{13}$-everyday tasks were ranked according to their difficulty on a $100 \mathrm{~mm}$ scale and patients asked to place a mark on the scale at a point above which their breathlessness would stop them; $(c)$ a six-minute walking test ${ }^{14}$ 
- patients walked in an enclosed corridor according to standardised instructions, each patient performing at least one practice test; and (d) a treadmill test $\mathrm{t}^{15-17}$ - patients walked on a horizontal treadmill with logarithmic increases in speed each minute to exhaustion $(1 \cdot 3$, $1 \cdot 8,2 \cdot 5,3 \cdot 3,4 \cdot 4,5 \cdot 9,8 \cdot 0,10 \cdot 8 \mathrm{~km} /$ hour). At the end of each minute patients scored breathlessness on a $10 \mathrm{~cm}$ visual analogue scale (not breathless-extremely breathless). This breathlessness score was then plotted against distance walked, and the distance walked at a breathlessness score of $5 \mathrm{~cm}$ was derived for each patient. The distance walked at exhaustion was also measured. All patients performed at least one practice test.

Exercise physiology-Patients performed a progressive exercise test to exhaustion on a bicycle ergometer (Instrument Lode, Groningen, Holland). Work load was increased by 100 kilopond meters/min every minute until exhaustion at a constant pedalling speed of $0.83 \mathrm{~Hz}$. Ventilation (Fleish No 4 pneumotachograph with Elema-Schonander pressure transducer), oxygen consumption (Servomex OA 272, response time 30 seconds), and carbon dioxide production (PK Morgan Capnograph, response time 15 seconds) were computed from mixed expired gases (nose clip and mouthpiece). Measurements were made during the third minute after steady state at rest and during each complete minute of exercise up to exhaustion.

All tests were performed on the same day, but at least one hour's rest was enforced between exercise tests. Data were entered into a Prime 400 series computer and comparisons between groups of data made with the Mann-Whitney $U$ test. Multivariate analysis was used to examine the possible interactions of lung function, disability, and exercise physiology.

\section{Results}

The table sets out the results. The two groups were closely matched for age and sex, but the hypercapnic subjects were significantly heavier than the normocapnic group.

Comparison of clinical, physiological, and exercise data between normocapnic and hypercapnic groups. Figures are means $(S D)$

\begin{tabular}{|c|c|c|c|}
\hline & $\begin{array}{l}\text { Normocapnic } \\
(n=15)\end{array}$ & $\begin{array}{c}\text { Hypercapnic } \\
(\mathrm{n}=11)\end{array}$ & $\begin{array}{c}\text { Significance } \\
\text { (Mann-Whitney } \\
\text { U test) }\end{array}$ \\
\hline $\begin{array}{l}\text { Age (years) } \\
\text { Sex }(\mathrm{F}: M) \\
\text { Weight }(\mathrm{kg})\end{array}$ & $\begin{array}{c}58 \cdot 9 \\
5: 10 \\
59 \cdot 9(10 \cdot 7)\end{array}$ & $\begin{array}{c}57 \cdot 5 \\
3: 8 \\
69 \cdot 6(12 \cdot 2)\end{array}$ & $\begin{array}{c}\text { NS } \\
p<0.001\end{array}$ \\
\hline $\begin{array}{l}\text { No receiving diuretics } \\
\text { (at time of study) }\end{array}$ & (2) & (2) & \\
\hline $\begin{array}{l}\mathrm{FEV}_{1}(1) \\
\mathrm{FVC}_{(1)}\end{array}$ & $\begin{array}{l}0.59(0.14) \\
1.79(0.61)\end{array}$ & $\begin{array}{l}0.62(0.14) \\
1.64(0.66)\end{array}$ & $\begin{array}{l}\text { NS } \\
\text { NS }\end{array}$ \\
\hline $\mathrm{T}_{\mathrm{LCO}}(\mathrm{mmol} / \mathrm{min} / \mathrm{kPa})$ & $3.61(1.32)$ & $4.77(2.37)$ & NS \\
\hline Haemoglobin $(\mathrm{g} / \mathrm{dl})$ & $15 \cdot 2(1.50)$ & $18 \cdot 2(0 \cdot 88)$ & $\mathrm{p}<0.01$ \\
\hline $\begin{array}{l}\mathrm{PaO}_{2} \text { at rest }(\mathrm{kPa}) \\
\mathrm{PaCO}_{2} \text { at rest }(\mathrm{kPa}) \\
\mathrm{PaO}_{2} \text { hyperventilation }(\mathrm{kPa})\end{array}$ & $\begin{array}{l}9 \cdot 3(1 \cdot 1) \\
4 \cdot 9(0 \cdot 4)\end{array}$ & $\begin{array}{l}7 \cdot 6(0.9) \\
6 \cdot 6(0.5) \\
9 \cdot 1(1 \cdot 3)\end{array}$ & $\begin{array}{l}\mathrm{p}<0.002 \\
\mathrm{p}<0.001\end{array}$ \\
\hline $\mathrm{PaCO}_{2}$ hyperventilation ( $\mathrm{kPa}$ ) & & $5 \cdot 6(1 \cdot 0)$ & \\
\hline $\mathrm{PaO}_{2}$ exercise $(\mathrm{kPa})$ & $8 \cdot 1(1 \cdot 4)$ & $7 \cdot 1(1 \cdot 1)$ & $\mathrm{p}<0.01$ \\
\hline $\mathrm{PaCO}_{2}$ exercise $(\mathrm{kPa})$ & $5.1(0.4)$ & $6 \cdot 1(1 \cdot 3)$ & $\mathrm{p}<0.01$ \\
\hline Dyspnoea grade & $4 \cdot 1(0 \cdot 6)$ & $3.6(1 \cdot 2)$ & NS \\
\hline $\begin{array}{l}\text { Oxygen-cost diagram } \\
\text { Distance walked at breathlessness }\end{array}$ & $48 \cdot 7(13 \cdot 8)$ & $47 \cdot 6(13 \cdot 7)$ & NS \\
\hline $\begin{array}{l}\text { Distance walked at breathlessness } \\
\text { score } 5 \text { on treadmill }(\mathrm{m}) \\
\text { Distance walked to exhaustion }\end{array}$ & $122(126)$ & $144(161)$ & NS \\
\hline 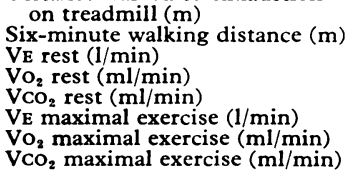 & $\begin{array}{l}218(141) \\
343(116) \\
11 \cdot 6(4 \cdot 2) \\
317(85) \\
266(72) \\
24 \cdot 3(8 \cdot 8) \\
712(199) \\
609(202)\end{array}$ & $\begin{array}{l}207(146) \\
289(104) \\
10 \cdot 1(2 \cdot 4) \\
360(87) \\
303(58) \\
16 \cdot 8(7.8) \\
763(306) \\
661(325)\end{array}$ & $\begin{array}{c}\text { NS } \\
\text { NS } \\
\text { NS } \\
\text { NS } \\
\text { NS } \\
p<0.02 \\
\text { NS } \\
\text { NS }\end{array}$ \\
\hline
\end{tabular}

NS = Not significant. $\mathrm{NS}=\mathrm{Not}$ significant.
carbon dioxide production.

\section{LUNG FUNCTION}

There were no significant differences in spirometric values between the two groups. Although mean $T_{L} \mathrm{CO}$ was higher in the hypercapnic group, this difference was not significant.

\section{BLOOD GAS TENSIONS}

The hypercapnic subjects were noticeably more hypoxic at rest than the normocapnic group (fig 1). All of the hypercapnic subjects could increase $\mathrm{PaO}_{2}$ and lower $\mathrm{PaCO}_{2}$ by hyperventilation to values close to those of the normocapnic group at rest. On maximal exercise both groups had a lower $\mathrm{PaO}_{2}$ and, though the fall in $\mathrm{PaO}_{2}$ was greater in the normocapnic group, the hypercapnic group remained significantly more hypoxic.

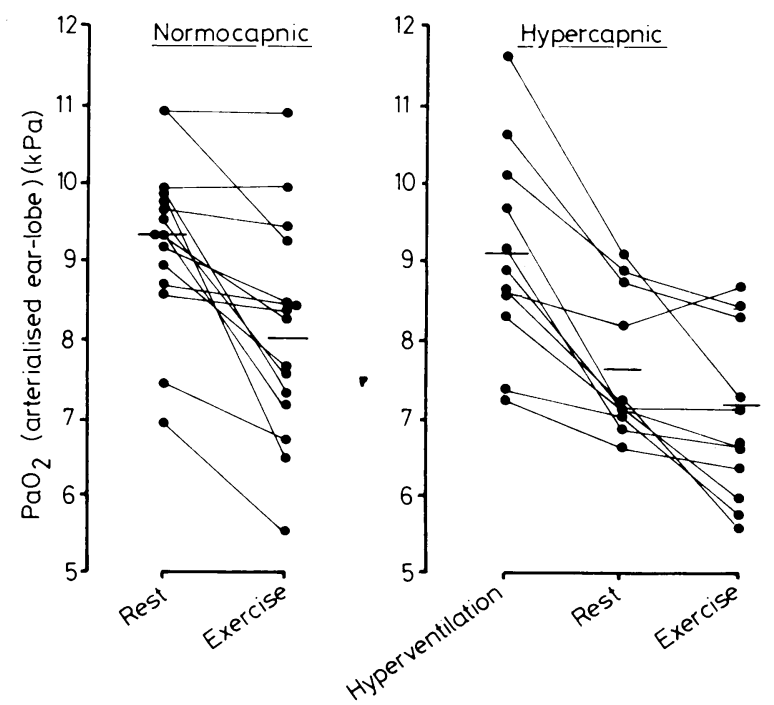

FIG 1-Arterialised ear-lobe oxygen pressure $\left(\mathrm{PaO}_{2}\right)$ at rest and on exercise in normocapnic and hypercapnic subjects and during hyperventilation in hypercapnic subjects. Bars are means.

Conversion: SI to traditional units- $\mathrm{PaO}_{2}: 1 \mathrm{kPa} \approx 7.5 \mathrm{~mm} \mathrm{Hg}$.

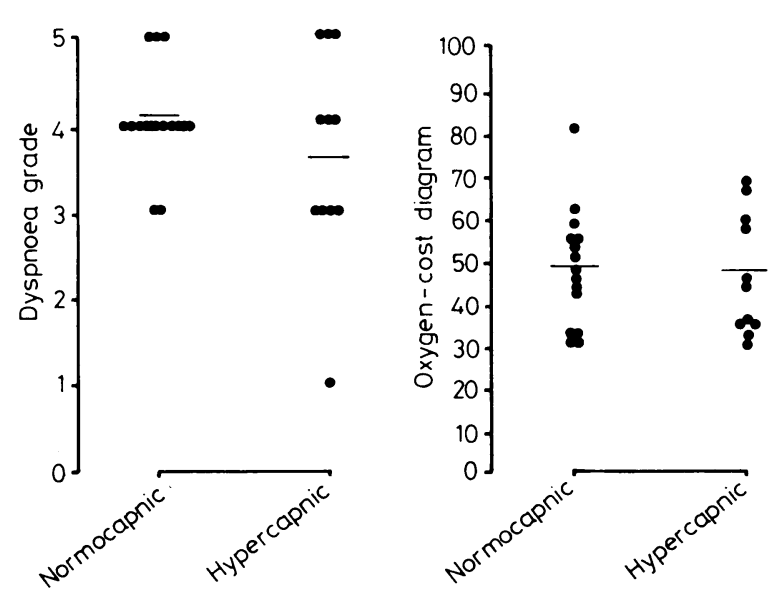

FIG 2-Subjective disability: dyspnoea grades and oxygen-cost diagram scores in normocapnic and hypercapnic subjects. Bars are means.

\section{BREATHLESSNESS AND EXERCISE TOLERANCE}

Subjective-There were no significant differences in the patients' assessments of disability (dyspnoea grade, oxygen-cost diagram) or breathlessness on the treadmill test between the groups (fig 2).

Objective-There was a wide variation in exercise tolerance (assessed by six-minute walking distance and distance to exhaustion on the treadmill) within both groups but no difference between them (fig 3).

Exercise physiology-There was no significant difference between the groups in resting ventilation, oxygen consumption, or carbon dioxide production. The ventilatory response to exercise was significantly steeper in the normocapnic group (fig 4). Thus the mean minute ventilation at maximal exercise was significantly greater in the normocapnic group (mean $24.31 v 16.81 / \mathrm{min}$ ) than in the hypercapnic group, when the mean oxygen consumption and carbon dioxide production for the two groups was roughly equal. 

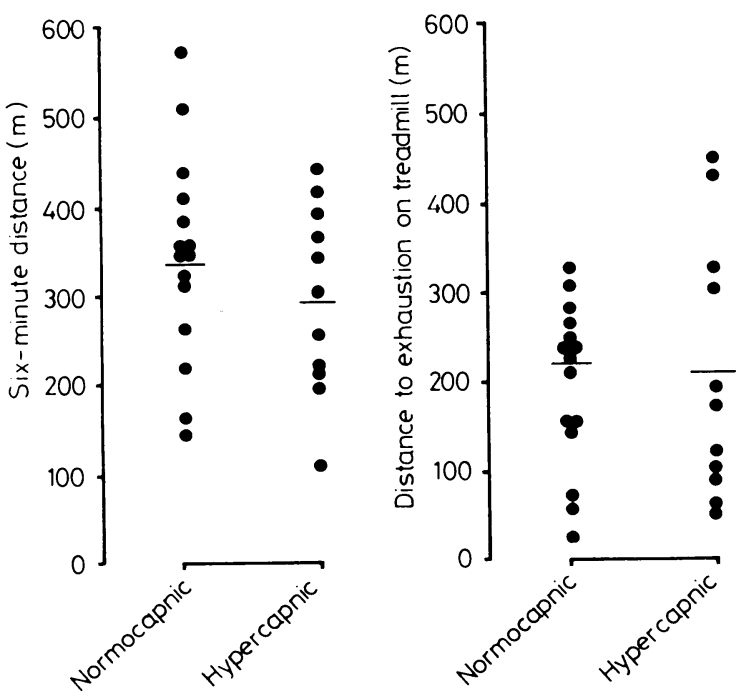

FIG 3-Exercise tolerance during six-minute corridor walk and progressive treadmill exercise in normocapnic and hypercapnic subjects. Bars are means.

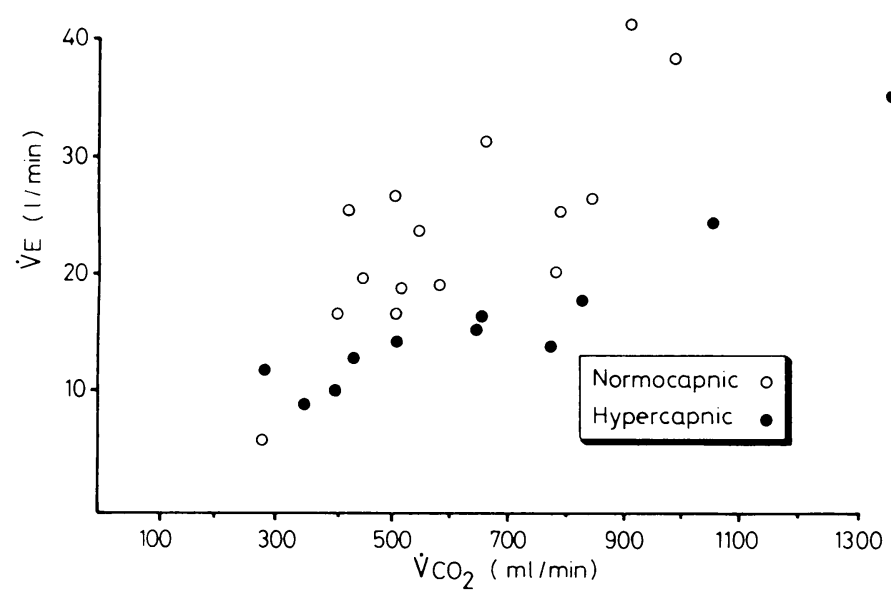

FIG 4-Ventilation (rate of expiratory gas flow; $\mathrm{VE}$ ) in relation to carbon dioxide production ( $\mathrm{VcO}_{\text {. }}$ ) during last completed minute of exercise on bicycle ergometer in the two groups of subjects.

\section{MULTIVARIATE ANALYSIS}

The influence of lung function $\left(T_{L} \mathrm{CO}, \mathrm{FEV}_{1}, \mathrm{FVC}\right)$ on exercise tolerance (maximal oxygen consumption, distance to exhaustion on treadmill, six-minute walking distance) was assessed by multiple correlation analysis. A combination of $\mathrm{T}_{\mathrm{L}} \mathrm{CO}$ and FVC was responsible for $41 \%, 30 \%$, and $32 \%$ of the variation in maximal oxygen consumption, distance to exhaustion on treadmill, and six-minute walking distance, respectively. $\mathrm{T}_{\mathrm{L}} \mathrm{CO}$ alone was the only important correlate with dyspnoea grade, being responsible for $45 \%$ of the total variation, but no single variable or group of variables interacted significantly with oxygen-cost diagram score.

\section{Discussion}

Several studies have assessed disability in different types of patients with chronic airflow limitation. ${ }^{918-21}$ Groups have been selected for various clinical, radiological, physiological, and blood gas criteria, which makes analysis difficult. For example, exercise tolerance is likely to be different in two groups selected for the presence and absence of emphysema, owing to the disparity in transfer factor. By selecting only on the basis of arterial blood gas tensions we attempted to match two groups for spirometric values and transfer factor and assess whether "fight- ing" to maintain relatively normal arterial blood gas tensions has a cost in terms of breathlessness or disability.

In our study the normocapnic subjects were thin, had relatively normal $\mathrm{PaO}_{2}$ and fewer episodes of right heart failure, and were clinically typical "pink puffers." The hypercapnic group were chronically hypoxic and all had had episodes of right heart failure and were clinically "blue bloaters." That the hypercapnic group "chose" to tolerate abnormal blood gas tensions was shown by their ability to improve $\mathrm{PaO}_{2}$ and $\mathrm{PacO}_{2}$ considerably towards normal by hyperventilation. We failed to show any difference in breathlessness or exercise tolerance between these two groups despite a higher ventilatory response to exercise in the normocapnic group. Burrows and Fletcher's transatlantic studies in the 1960 s failed to show a difference in dyspnoea grade in patients divided into "emphysematous" and "inflammatory" groups on radiological and physiological grounds. ${ }^{1819}$ Jones $^{9}$ did find reduced exercise tolerance in patients with "emphysema" compared with "bronchitis," but those with emphysema had worse spirometric results (by $15 \%$ ) and transfer factor values (by $50 \%$ ) than the bronchitic group. Conversely, Marcus $e t a l^{20}$ and Filley et $a l^{21}$ failed to show any difference in exercise tolerance, despite an increased ventilatory response to exercise in patients selected for emphysema.

There was considerable variation in exercise tolerance, breathlessness, and disability within the patient groups which was independent of resting $\mathrm{PaCO}_{2}$. Multivariate analysis of the data for all patients showed that a proportion of the disability could be attributed to the relative severity of spirometric and diffusion abnormalities. In both groups, however, some patients seemed to have a disproportionately good exercise tolerance in the face of very severe airflow limitation, and psychological factors, especially motivation and depression, ${ }^{1722}$ are equally if not more important. Body weight may also be important in the performance of walking tests, hypercapnic patients being at a disadvantage as compared with lighter, normocapnic patients.

There was a disparity between ventilation and breathlessness on exercise between the two groups, and it is clearly wrong to think of ventilation and breathlessness as synonymous. Breathlessness, when measured by visual analogue scales during exercise both in normal subjects and in patients with chronic airflow limitation, correlates well with ventilation within an individual but poorly between individuals-that is, there is a wide variation of the perception of a given ventilation as breathlessness. ${ }^{17}$ Arguably, since blue and bloated patients are equally breathless and disabled but have a lower ventilatory response to exercise, they might be actually more breathless for equivalent ventilation. Also recent work shows that arterial hypoxia and hypercapnia may potentiate the feeling of breathlessness at a given ventilation. ${ }^{23}{ }^{24}$ This together with other factors such as respiratory muscle function and position and possible differences in acid-base balance secondary to diuretic treatment make a direct comparison of breathlessness with ventilation highly complex.

The misconception that pink and puffing patients are more breathless may have arisen from the increased ventilatory response to exercise, so that patients are seen to puff and thus look breathless. It may also reflect differences in way of life, with the pink puffer playing the hare, always rushing at life, in contrast with the tortoise blue bloater, who plods at one pace and never becomes breathless.

This work was supported by grants from the clinical research committee of Brompton Hospital and the Tobacco Advisory Council.

\section{References}

1 Dornhorst AC. Respiratory insufficiency. Lancet 1955;i:1185-6.

2 Reid L. In: Fishman AP, ed. Pulmonary diseases and disorders. New York: McGraw Hill, 1980:524.

${ }^{3}$ Emerson P, ed. Thoracic medicine. London: Butterworths, $1981: 473$.

${ }^{4}$ Forster HV, Dempsey JA. In: Hornbein TF, ed. Regulation of breathing 
part II. New York: Marcel Dekker, 1981 :ch 13. (Lung biology in health and disease. Series. Vol 17.)

${ }^{5}$ Robin ED, O'Neill RP. The fighter versus the non-fighter. Control of ventilation in chronic obstructive lung disease. Arch Environ Health $1963 ; 72: 125-7$

${ }^{6}$ Rosser R, Guz A. Psychological approaches to breathlessness and its treatment. $\mathcal{F}$ Psychosom Res 1981 ;25:439-47.

${ }^{7}$ Anonymous. Centrally acting drugs in chronic airways obstruction. $\mathrm{Br}$ Med f 1980;281:1232-3.

${ }^{8}$ Anonymous. Diazepam and breathlessness. Lancet 1981 ;ii:242-3.

${ }^{9}$ Jones NL. Pulmonary gas exchange during exercise in patients with chronic airway obstruction. Clin Sci 1966;31:39-50.

${ }^{10}$ Matthews AW. The relationship between central carbon dioxide sensitivity and clinical features in patients with chronic airways obstruction. $Q \mathcal{Y}$ Med 1977;46:179-95.

${ }^{11}$ Cotes JE. Lung function: assessment and application in medicine. 3rd ed. Oxford: Blackwell Scientific, 1975.

12 Spiro SG, Dowdeswell IRG. Arterialised earlobe blood samples for blood gas tensions, $B r \mathcal{F}$ Dis Chest $1976 ; 70 \cdot 263-8$.

${ }^{13}$ McGavin CR, Artvinli M, Naoe H, McHardy GJR. Dyspnoea, disability, and distance walked: comparison of estimates of exercise performance in respiratory disease. $\mathrm{Br} M e d \mathcal{F} 1978 ;$ ii :241-3.

14 Butland RJA, Pang JA, Gross ER, Woodcock AA, Geddes DM. Two-, six-, and twelve-minute walking tests in respiratory disease. $\mathrm{Br} \mathrm{Med} \mathcal{F}$ $1982 ; 284: 1607-8$.

15 Woodcock AA, Gross ER, Gellert A, Shah S, Geddes DM. Breathlessness and exercise tolerance in subjects with airways obstruction and normal blood gases: the effects of dihydrocodeine, alcohol and caffeine. $N$ Engl f Med $1981 ; 305: 1611-6$.

16 Woodcock AA, Gross ER, Geddes DM. Oxygen relieves breathlessness in pink puffers. Lancet $1981 ; \mathrm{i}: 907-9$.

17 Woodcock AA. MD thesis. Breathlessness in man: measurement and modification. University of Manchester, 1982.

${ }^{18}$ Burrows B, Niden AH, Fletcher CM, Jones N. Clinical types of chronic obstructive lung disease in London and in Chicago. Am Rev Resp Dis $1964 ; 90: 14-27$.

${ }^{19}$ Fletcher CM, Jones NL, Burrows B, Niden AH. American emphysema and British bronchitis. Am Rev Resp Dis 1964;90:1-13.

${ }^{20}$ Marcus JH, McLean RL, Duffell GM, Ingram RH. Exercise performance in relation to the pathophysiologic type of chronic obstructive pulmonary disease. Am 7 Med 1970;49:14-21.

21 Filley GF, Beckwitt BJ, Reeves JT, Mitchell RS. Chronic obstructive bronchopulmonary disease: II oxygen transport in two clinical types. Am $\mathcal{F}$ Med 1968;44:26-37.

22 Morgan AD, Peek DF, Buchanan D, McHardy GJR. Psychological factors and beliefs affecting exercise tolerance in chronic bronchitis. Clin Sci 1982;63:40P.

${ }^{23}$ Adams L, Chronos N, Guz A. The dyspnogenic effect of hypoxiadissociation from ventilatory response. Clin $S c i$ 1982;63:17P.

24 Guz A, Adams L, Minty K, Murphy K. Breathlessness and the ventilatory drives of exercise, hypercapnia and hypoxia. Clin $S c i$ 1981;60:17p-18p.

\title{
Vitamin D state of Asians living in Pakistan
}

\author{
A RASHID, T MOHAMMED, W P STEPHENS, S WARRINGTON, J L BERRY, E B MAWER
}

\begin{abstract}
Asians living in Pakistan have serum 25-hydroxycholecalciferol concentrations which are well within the normal range and significantly higher than in Asians resident in Britain. Clearly, Asians can maintain an adequate vitamin $D$ state given an abundant supply of ultraviolet light, and the expression of vitamin $D$ deficiency is an environmental and not a genetically determined characteristic.

The risk of an Asian developing vitamin $D$ deficiency increases after migration to Britain. The most efficient way to treat this is by supplementation with vitamin $D$.
\end{abstract}

\section{Introduction}

Asian immigrants to the United Kingdom are known to be at risk of developing osteomalacia or rickets. ${ }^{1}$ The numbers developing clinical bone disease are relatively small, ${ }^{2}$ but between $33 \%$ and $44 \%$ of Asian immigrants have biochemical evidence of vitamin $\mathrm{D}$ deficiency with low serum concentrations of 25 -hydroxycholecalciferol ${ }^{3}(25(\mathrm{OH}) \mathrm{D})$. The aetiology of the

Crumpsall Hospital, Manchester

A RASHID, $\mathrm{MB}, \mathrm{CHB}$, house physician

Manchester Royal Infirmary, Manchester M13 9WL

T MOHAMMED, MB, CHB, house physician

W P STEPHENS, MD, MRCP, senior registrar in medicine

Birch Hill Hospital, Rochdale, Lancashire

S WARRINGTON, BSC, district dietitian

University of Manchester, Manchester M13 9PL

J L BERRY, PHD, research fellow

E B MAWER, PHD, senior research fellow condition remains controversial and various environmental and genetic factors have been implicated. Inadequate habitual solar exposure, dietary practices, skin colour, and an entirely speculative "metabolic defect" have all been suggested. Despite this controversy there is very little information on the biochemical vitamin $\mathrm{D}$ state of Asians living in their home country, and such information might provide a valuable insight into the factors causing the low serum $25(\mathrm{OH}) \mathrm{D}$ concentrations among immigrants to Britain.

We have compared the vitamin D state of Pakistanis residing in Rochdale, Lancashire (latitude $53^{\circ} 26^{\prime} \mathrm{N}$ ), with that of a group of Pakistanis residing in the Punjab (roughly $29^{\circ} \mathrm{N}$ ).

\section{Subjects and methods}

Of the 262 Asians seen in a large survey of Rochdale Asians," 90 hailed from the Lahore and Rawalpindi area of Pakistan. These subjects were interviewed by AR and TM and contact addresses of relatives in Pakistan obtained. During a subsequent visit to Pakistan in the summer of 1981 attempts were made to trace these relatives and to solicit their help with the study. In the event, 92 indigenous Pakistanis ( 48 male, 44 female) were investigated. Nineteen of these were first-degree relatives of immigrants to Britain, and the remaining 73 were recruited from among the neighbours of relatives declining to take part in the study. The median age of these subjects was 29 years. There was one 11 -year-old, and the remainder ranged from 14 to 75 years. They were considered to be highly representative of the community from which the Asian immigrants to Britain had originated. Of the 92 subjects, 31 were villagers and 61 were city dwellers.

All participants in the study underwent venesection, and the frozen serum was returned to Manchester for measurement of the serum $25(\mathrm{OH}) \mathrm{D}$ concentration by competitive protein-binding assay. ${ }^{2}$ Clinical evidence of vitamin $D$ deficiency was sought by questioning and by examination, and a dietary history was taken by the seven-day recall method to ascertain the dietary intake of vitamin D. 